Available online at www.jmle.org

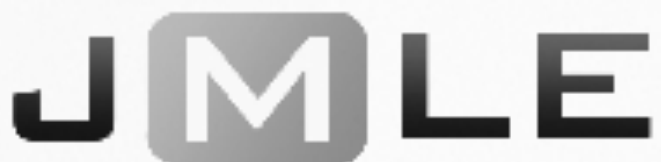

The National Association for Media Literacy Education's

Journal of Media Literacy Education 9 (2), 30 - 44

\title{
Digital Media Production to Support Literacy For Secondary Students with Diverse Learning Abilities
}

\author{
April Marie Leach \\ G-Star School of the Arts for Film Animation \& Performing Arts
}

\begin{abstract}
Producing digital media is a hands-on, inquiry-based mindful process that naturally embeds Universal Design for Learning (UDL) principles into literacy instruction, providing options for learning and assessment for a wide array of students with diverse learning abilities. Video production learning experiences acknowledge the cognitive talents of some students labeled "disabled." For some, the discovery of personal abilities activated when learning through the production process may motivate deeper learning. Although challenges of access, quality of teacher preparation and assessment strategies represent significant challenges, digital media production learning experiences offer diverse learners a rich, socially interactive environment that models open communication and excitement for learning, and supports the scaffolding of comprehension skills for learning academic content.
\end{abstract}

Keywords: literacy, digital media production, video, adolescents, secondary students, diverse abilities, disabilities

When Universal Design for Learning (UDL) principles are incorporated within digital media production experiences as a means to teach literacy, it may expand opportunities and reduce barriers for students with diverse learning abilities and challenges. Media and its production is a ubiquitous present-day mode of communication due to the transition from analog to digital technologies resulting in global Internet connectivity (Cope \& Kalantzis, 2009). Analogous to the use of print text, digital media is now read, examined critically, and written in "visual and interactive languages" (Capello, Felini, \& Hobbs, 2011, p. 68) for social, entertainment, and learning purposes. Correspondingly, to be considered literate in this era of digital media, explicit instruction in critical cognitive and 
metacognitive thinking is necessary as students with diverse learning abilities and challenges are taught how to interpret and compose fluently using these modes of communication (McMaster, Espin, \& Van den Broek, 2014; Smith, 2014).

The term "disabilities" can describe learners who bring language-based, social, behavioral, nonverbal, physical, sensory-based, and psychological issues to the learning process (Lanter, 2005; Souma \& Casey, 2015). Therefore, the term "diverse learning abilities and challenges" replaces "disabilities" in this article purposely. Academic text-based culture of learning is expanding to include myriad forms of digital media. Producing media may invite collaborative, conceptual, and creative talents formerly considered non-academic into the learning process, making it more engaging, especially for those for whom traditional pedagogy has not been either engaging or effective (Glass, Meyer, \& Rose, 2013). Students characterized as learning disabled could gain confidence in their digital media production abilities as they contribute previously unrecognized thinking and learning perspectives to learning processes (Brasseur-Hock, Hock, Kieffer, Biancarosa, \& Deshler, 2011; Cantrell et al., 2014; Gardner \& Davis, 2013; Stankov, Morony, \& Lee, 2014).

What follows will show how UDL and digital media production offer opportunities to foster inquiry, collaboration, and discourse in modes that engage all students in the learning process. The processes required to conceptualize and produce media for educative and assessment purposes embody the three main research-based UDL principles by offering multiple means of action and expression, representation, and engagement (CAST, 2011). Links between social interaction and engagement have been theoretically and empirically shown to increase student engagement and impact student learning and development (Pianta, Hamre, \& Allen, 2012). Opportunities for social interaction, such as collaboration and discourse, contribute to an engaging inquiry-based learning environment (Anderson, 2010). In such an environment, students mesh abilities collaboratively to construct understandings of academic content that link traditionally discrete subject areas through discussion, research, reading, writing, filming, and editing as they produce digital media across K-20 curricula (CAST, 2011; Hubbard, 2012).

\section{Intersection of Core Principles and Competencies of Media Literacy Education with Universal Design for Learning}

The six core principles of media literacy education, (National Association for Media Literacy Education [NAMLE], 2007) along with the five digital and media literacy competencies set forth by Hobbs (2010) are congruent with research-based instructional literacy practices. Implemented in the classroom, UDL principles foster inquiry, collaboration, and discourse in modes that engage all students, allow their voices to be heard, and make learning meaningful. UDL contributes the research-based theoretical framework, while digital media literacy competencies develop real-world skills transferable across disciplines and to the workplace. Together, UDL and digital media literacy support an inclusive, emotionally supportive framework for designing and teaching literacy learning activities to students who bring diverse learning abilities and challenges to the 
classroom. The five digital and media literacy competencies cultivate critical $21^{\text {st }}$ century thinking and develop proficiency in the Common Core State Standards (CCSS, 2010) by offering students practice in what I term "ZZ Logic" - it's the ability to zoom in and zoom out conceptually to understand the larger perspective as well as the smallest details.

\section{Theoretical Framework/Perspectives}

The UDL Guidelines (2017) include options for providing multiple means of representation, action and expression, and engagement to encourage purposeful, motivated learners. Student-centered options that contribute to sustaining effort, persistence, and recruiting interest include fostering collaboration and community and optimizing individual choice, autonomy, relevance, and authenticity (Lewis-Charp \& Law, 2014). Students can employ all attributes of media production processes to demonstrate comprehension of complex concepts that manifest Common Core Standards and align with UDL (CAST, 2016).

Given the importance of learner engagement, other relevant theories include positive psychology flow theory, where engagement and learning occur in the balance between challenge and skill (Csikszentmihalyi, 1990), and the cognitive/constructivist psychology of embodied learning theory (Pouw, Van Gog, \& Paas, 2014). These theories feature prominently in thinking about the components of literacy curricula most effective in engaging learners and teaching the spectrum of literacy to students with diverse abilities and challenges (Stolz, 2014). Contributing perspective to embodied learning for students with diverse abilities are the twin cognitive processes of transduction and transmediation. Transduction occurs as knowledge is synthesized and then reconfigured across different modes of expression to express the same understanding, such as information from text to film while transmediation describes the representation of knowledge known in language form into an art form (Harste, 2014). These perspectives build on the empirical evidence which finds that constructivist project-oriented media production offers access to learning that is inclusive of students with diverse learning abilities (Hubbard, 2012).

\section{Producing Digital Media to Support Literacy for Students with Diverse Abilities and Challenges}

In 2010 Hobbs published a white paper reframing literacies now available into an access, analyze, create, reflect, and act (AACRA) model for instruction (Hobbs, 2010). Hobbs explained that in the digital age, everyone should be able to access and analyze information, create messages, reflect on media influences, and be able to act using all these literacies in a socially responsible manner. Recently, Hobbs broadened the ACCRA model to include the latest additions to education technology: virtual reality and augmented reality (Hobbs, 2016).

The reasons for including multiple forms of media into literacy instruction, especially for secondary students with diverse learning abilities emerged from constructivist and embodied learning frameworks (Dewey, 1934; Pouw et al., 2014). As diverse learners develop inherent abilities, mixed-media 
options offer powerful assists in expanding learners' knowledge, life, and work skills through the social and cultural supports of collaborative learning with technology (Friesem, 2016).

Mixed-media learning environments (MMLE) afford students multiple entry points into participation. Students, who come to these flexible environments with different skills, inclinations, and literacies, have increased opportunities for expression and for development of expertise and, thus, for finding their niches, where they willfully contribute to collaborative efforts and receive group esteem. Also, residual classroom artifacts created in MMLE support continuity in contentspecific learning processes, thus facilitating social construction of knowledge. Finally, leading mixed-media activities requires able facilitators who can sensitively engage and leverage students' diverse interests, talents, and perspectives in patiently steering this richness towards rewarding learning experiences (Abrahamson, et al., 2005, p.2).

Through the lens of collaborative learning theory, Jeong and Hmelo-Silver (2016) posited that by communicating, sharing resources, engaging in joint tasks and productive collaborative learning processes, students learn to monitor and regulate collaborative learning as they find and build groups and communities. Leu, Kinzer, Coiro, and Cammack (2004) discussed emerging theoretical perspectives to teach new literacies required for online reading, writing, and communicating.

One question the authors brought forth for further research and discussion was, "How can you apply the recommendation for 'collaborative online reading and writing practices [that] appear to increase comprehension and learning"'? In response, Henry, Castek, O'Byrne, and Zawilinski (2012) conducted a comparative case study in which they investigated collaborative online reading and writing practices using an empowerment model that included studentcentered techniques, which they termed Internet Reciprocal Teaching. The researchers found that collaboration among struggling readers shifted the dynamic as students became more engaged, taking more active ownership of their roles as learners. Extending the implications of these findings is an inquiry model of instruction that used a framework termed Personal Digital Inquiry (PDI) (Coiro, Castek, \& Quinn, 2016).

Literacy research that examines "hands-on" learning, is synonymously described as "embodied" or "kinesthetic" learning (Abrahamson, Gutierrez, Charoenying, Ngrete, \& Bumbacher, 2012). One researcher explains it this way:

The idea is to design interactive learning activities... geared to recruit children's natural ways of engaging the world...by actively perceiving and acting on it. The rationale is that children can learn curricular content by first solving a hands-on, or perhaps "body-on" problem and only later formalizing their solution using vocabulary, diagrams, symbols, and other forms of reference that shift their understanding into professional ways of talking and thinking (Abrahamson, 2017, para. 11). 
Producing digital media fits this definition of being a hands-on, inquirybased mindful process (Spires, Hervey, Morris, \& Stelpflug, 2012). Studies have shown that active learning involving media production is both engaging and effective for a wide spectrum of learners with diverse abilities (Leach, 2015; Smith, 2014), offering additional evidence in support of UDL pedagogical practices.

\section{The Multimodal Media Literacy Project}

In 2015, I conducted a case study at the secondary level with a sample of students in four intensive reading classes at a media arts magnet high school to investigate how struggling adolescent readers immersed in a multimodal media literacy project experienced motivation to read, comprehension of informational text, and overall academic engagement. One-third of the sample were diagnosed with learning disabilities and/or were English language learners, one-half had been retained in previous grades, and one third were learning disability undiagnosed, but were in intensive reading classes due to low standardized reading comprehension scores. This sample was observed during an eight-week multimodal media literacy project guided by the driving question:

How has the $20^{\text {th }}$ century decade you chose to investigate impacted our lives today in the fields of science, social studies, and literature/culture? (Leach, 2015).

To explore this question, students had to create a multimodal media presentation to share their findings. Working in groups of three, students were led through instructional practices that scaffolded comprehension skills. At each of the project stages students read and viewed text and media multiple times individually and then together, wrote narrative summaries of content they would like to share in their presentation, discussed the merits of each of the contributor's ideas, learned vocabulary of the time period, played music, read poetry, and explored and described art, fashion, and the scientific discoveries and historical events that occurred. These learning activities were detailed in the weekly project timeline, and organized in the following order: online research, summarizing, creating a timeline to tell their decade story, storyboarding, writing the narrative, composing with media of their choice, editing, and presenting their completed multimodal media project.

In follow-up one-on-one interviews, every student volunteered that they wished they could learn this way in all their subject areas, stating that in learning through multimodal media, they might even come to like their most difficult subjects (Leach, 2015). Student artifacts from the research study illustrated the power of multimodal media learning for diverse learners.

One example was the final project, The Fifties News created by three male students. Students created a "hip" news program about cultural, political and social issues of the 1950s. Topics include the cure for polio, the Korean War, pop art, the emerging civil rights movement and the rise of television. Through the 
episode, students use phrases like "nifty" and "grand" in ways that demonstrate their awareness of historical changes in language use.

Among the team members, one was an ELL student, one had a diagnosed disability, and one was previously retained. It bears noting that one student in this group (a young man with diagnosed learning disabilities) was in danger of not graduating because he slept through every class in school. He claims he did not sleep once during the eight-week project; he proceeded to pass a standardized reading test required for graduation and graduated. Overall academic engagement was so high among study participants, that after the study ended, reading teachers assigned additional multimedia literacy projects for their classes of learners with diverse abilities and challenges. Figure 1 shows a screen shot of "Bad News Bernie," the stage name of the student anchor of The Fifties News.

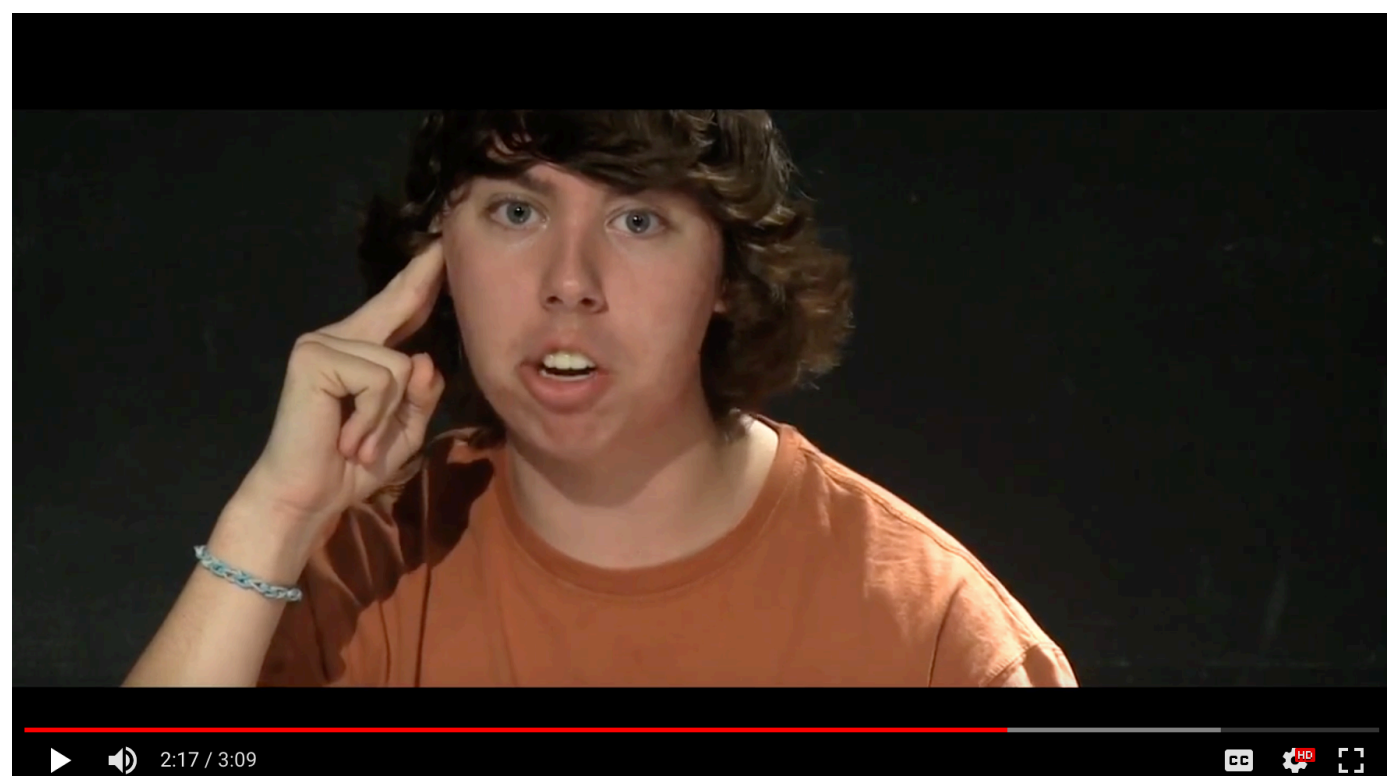

Figure 1

Bad News Bernie hosts The Fifties News

Another group of students created public service announcements for improving air quality created by students for one of the subsequently assigned projects using similar reading comprehension scaffolds in reading teacher Elise Klein's Intensive Reading classroom: Public Service Announcement - Air, Public Service Announcement - Pythons (G-Star School for Film Animation and Performing Arts, 2015).

\section{Preparing Teachers to Teach Literacy through Media Production}

While some teachers see the benefit of active hands-on learning and conduct this pedagogy in their classrooms (Yang, 2016), many others are not. This gap is under examination by a nationally funded five-year investigative center headed by Dr. William Penuel of the National Center for Research in Policy and Practice, 2016. Their mission is to understand how to make research more meaningful for teachers and educational leaders by coding research use, understanding the enablers among district administrators in making decisions 
about instructional practice, and examining attempts to increase the use of research in curricula by promoting interaction between researchers and practitioners.

This gap appeared in a mixed methods study sponsored by the International Literacy Association (ILA), conducted by the Task Force for Teacher Preparation for Literacy Instruction, of which I was a member. We were charged with gathering information about how PK-12 teacher certification programs prepared teachers to support literacy (Swaggerty et al., 2016). The deans of 1,200 traditional teacher education colleges in every state were sent a survey. Responses were received from college deans in 38 states and follow-up interviews were conducted. One finding was that teacher preparation in the pedagogy of literacy curricula that incorporated student-created media is not currently a part of most traditional teacher preparation programs in the United States (Swaggerty et al., 2016).

\section{Assessing Media Production as Curricula to Support Literacy for Diverse Learners}

Learning analytics are being developed to build iteratively and dynamically on constructivist learning theory to address the challenge of assessing media and project-based assignments to provide a broader picture of student learning processes (Worsley \& Blikstein, 2013). According to one researcher:

Traditional assessments, which focus on learning outcomes, seem incongruent with the process-oriented goals of project-based learning. Multimodal interfaces and multimodal learning analytics hold significant promise for assessing learning in open-ended learning environments. With its rich integration of a multitude of data streams and naturalistic interfaces, this area of research may help usher in a new wave of education reform by supporting alternative modes of learning (Worsley, 2012).

To address concerns regarding the assessment of learning in complex hands-on learning environments, learning analytics researchers have begun to develop assessment models that are able to take into account these complexities to ascertain what students are learning in these new learning spaces (Koh, Shibani, Pei-Ling Tan, \& Hong, 2016). In continuing to investigate means of assessing hands-on learning environments, it is important for educators to deepen their research into curricula. Doing so will allow secondary students with diverse learning abilities and challenges to develop literacy skills through media production using pedagogy and assessment tools currently available, such as formative feedback and multimodal rubrics.

\section{Discussion}

The value of student engagement as a relational process integral to academic achievement reiterates the need for building student-based curricula concurrently with teacher capacities that reinforce positive dynamic interactions 
among teachers and students (Lewis-Charp \& Law, 2014). Teacher preparation in the pedagogy of literacy curricula that incorporate student-created media is not currently part of most traditional teacher preparation programs in the United States (Swaggerty et al., 2016). Yet, many deans of teacher education institutions are aware of the need for such instruction (J. Cohen, personal communication, February 12, 2016).

Supporting academic achievement through engaging learning activities is especially critical for adolescents with diverse learning abilities and challenges who are at an even higher risk of dropping out of school than their contemporaries (Christensen \& Thurlow, 2004; Rumberger \& Rotermund, 2012). A socially interactive environment that models open communication and excitement for learning, and which is supported by instructional practices that scaffold comprehension skills of academic content, is clearly a goal for reaching and teaching that is inclusive of the needs of diverse learners (Guthrie, Wigfield, \& You, 2012). An example of such an environment is a classroom that has access to 1:1 technology, is arranged to facilitate student collaboration, and where on-task discourse is explicitly taught and nurtured as in the above study (McElhone, 2012). Teaching media production to students at the secondary level with diverse learning abilities, and as a curriculum that supports literacy across disciplines, is fraught with challenges due to the many attributes each student brings to the classroom. However, such a curriculum is also replete with possibilities which offer potential to broaden the spectrum of what it means to access, reflect, analyze, create, and act, academically and as a citizen of a democracy (Hobbs, 2010).

Media production learning experiences can support literacy learning for learners with diverse abilities, but this instructional strategy has limitations due to access to available technology, quality of teacher preparation, and approaches to assessment. In some communities, access to devices and assistive technologies for those who need alternative Internet access at school and at home can be limited. Presently, few teacher preparation programs support future teachers in learning to teach such a curriculum. A systematic program of professional development to build capacity for teachers already in schools does not yet exist. In this regard, Marc Tucker (head of the National Center for Education and the Economy), explains the limitations that exist between research and the Common Core State Standards upon which high stakes standardized assessment are based. He notes:

Well-crafted student performance standards are an essential ingredient in the educational equivalent of the modern high performance education system, but they will make no difference at all to student performance unless the other parts of the education system are crafted to use those standards to get the desired results (Tucker, 2016, para 7).

As a secondary literacy and instructional coach responsible for professional development at a public charter high school with 1,000 students, I work in a school where filmmaking, animation and performing arts are taught. Yet, the only classrooms with 1:1 computers are located in the film department. There are only 
two laptop carts teachers may reserve and one iPad cart with first generation devices with limited capacity. The media center has 40 computers, but it is in use much of the year for mandated standardized testing. While the teachers at my school receive professional development to utilize technology and media literacy, implementation is only possible if enough students have smartphones. These are the realities that many secondary teachers experience in the United States today.

Producing media as a means to advance academic learning and assessment is a young discipline that is still being defined (Miller, 2013). As a systematic approach is developed, it will contribute to teachers' abilities to use media production with students of diverse abilities without constraining them to a formulaic template robbing the learners of the experiences of immediacy and relevance (Barron \& Darling Hammond, 2008). This is where the work that is being done in learning analytics becomes important. Mining multimodal data in hands-on learning environments (Transformative Learning Technologies Lab, 2016) for assessment purposes (Schneider \& Blikstein, 2015) will be an aid to developing curricula to support literacy for secondary students with diverse learning abilities through digital media production.

The promise of digital media production to support literacy for secondary students with diverse learning abilities and challenges is not only appealing, it is possible, and it is being done. Research from the fields of education research into motivation, engagement, reading comprehension, positive psychology, cognitive psychology, learning analytics, and the role of technology indicate that when the principles of UDL are incorporated into pedagogy and curricula, expanded modalities for learning, such as digital media production, benefit students.

As we approach the middle of the $21^{\text {st }}$ century, tools for teaching and assessing learning are emerging that facilitate the implementation of the theories discussed and piloted in validated studies. A groundswell of materials, resources and software both from the private sector and academia are initiating changes that are transforming traditional templates of education; this results in increased inclusiveness as well as increased quality of teaching and rigor of Common Core aligned assignments. As has been shown, new models for learning and assessing are emerging and entering teacher preparation programs in response to data and research (Swaggerty et.al, 2016). New directives in public education policy show that government policy makers are attuned to these developments (Tucker, 2016; U.S. Department of Education Office of Educational Technology, 2016).

\section{Application}

- Access - Media Production can support literacy across content areas by offering UDL alternatives to how information is displayed and presented, with alternatives available for accessing auditory and visual information. Access to options for language learning such as vocabulary can be embedded as hypertext links or presented in graphic forms, symbols, or illustrations. Access to academic concepts can be illustrated through alternatives to text such as dance, video, graphic novels, photographs, storyboards, animation and physical enactment through acting or hands-on creating. 
- Create - Transforming information from one form to another, or transduction, allows for individuation of meaning making; one of the UDL recommended ways of providing multiple means of representation. Producing media, also explained herein as a form of transmediation, allows students to bring their identity and self-expression to academic pursuits, engaging their diverse learning capacities as they develop critical reading, writing, and thinking skills.

- Analyze - When UDL guidelines for utilizing multiple means of representation, action and expression are incorporated in the teaching of critical thinking, developing arguments, and the capacity to order thoughts logically, the analytical process can come alive for students. Teaching students to analyze information and ideas critically with embodied, handson, minds-on learning by creating mixed-media supports Common Core critiquing, analyzing, and speaking and listening skills. Furthermore, as students gain academic competency in analysis skills across a variety of means of representation and expression, they learn to self-regulate their ability to concentrate and persist in their endeavors, one of the UDL objectives.

- Reflect - Incorporating this competency through discourse and making meaning through alternative demonstrations of knowledge foster collaboration and communication according to the UDL principle of providing multiple means of engagement. The process of reflection encourages students to be metacognitive about their thinking, and to respond to and offer feedback with their peers as they reflect upon concepts and ideas across media. Additionally, thinking through academic concepts by creating a media presentation shifts the response to informational text and academic concepts from the efferent (factual) to aesthetic (artistic) mode, making learning personal.

- Act - By providing options for recruiting interest, UDL guidelines support the self-determination of students by providing opportunities for them to engage in authentic relevant learning activities. Empowering students with diverse learning abilities with the confidence and tools to communicate through media production, prepares them for active participation in their lives and as citizens of a democracy.

\section{References}

Abrahamson, D. (2017). Embodiment and mathematical learning. In K. Peppler (Ed.), The SAGE encyclopedia of out-of-school learning (pp. 247-252). New York. SAGE

Abrahamson, D., Blikstein, P., Lamberty, K.K., \& Wilensky, U. (2005). Mixedmedia learning environments. Instructional Design and Children. Proceedings of the Fourth International Conference for Interaction Design and Children, Boulder, CO, pp.1-2.

Abrahamson, D., Gutierrez, J., Charoenying, T., Ngrete, A., \& Bumbacher, E. (2012). Fostering hooks and shifts: Tutorial tactics for guided 
Mathematical discovery. Technology, Knowledge \& Learning 17(1/2), 6886. https://doi.org/10.1007/s10758-012-9192-7

Anderson, J. (2010). Interdisciplinary project-based learning leads to success. Tech Directions, 70(4), 20-21.

Barron, B., \& Darling-Hammond, L. (2008). Teaching for meaningful learning: A review of research on inquiry-based and cooperative learning. In L. Darling-Hammond, B. Barron, P. D. Pearson, A. H. Schoenfeld, E. K. Stage, T. D. Zimmerman, G. N. Cervetti, and J. Tilson (Rds.). Powerful Learning: What We Know About Teaching for Understanding. San Francisco, CA: Jossey-Bass. Retrieved from https://www.edutopia.org/pdfs/edutopia-teaching-for-meaningfullearning.pdf

Brasseur-Hock, I. F., Hock, M. F., Kieffer, M. J., Biancarosa, G., \& Deshler, D. D. (2011). Adolescent struggling readers in urban schools: Results of a Latent Class Analysis. Learning and Individual Differences, 21, 438-452. https://doi.org/10.1016/j.lindif.2011.01.008

Cantrell, S. C., Almasi, J. F., Rintamaa, M., Carter, J. C., Pennington, J., \& Buckman, D. M. (2014). The impact of supplemental instruction on lowachieving adolescents' reading engagement. The Journal of Educational Research, 107(1), 36-58. https://doi.org/10.1080/00220671.2012.753859

Capello, G., Felini, D., \& Hobbs, R. (2011). Reflections on global developments in media literacy education: Bridging theory and practice. Journal of Media Literacy Education, 3(2), 66-73. Retrieved from http://digitalcommons.uri.edu/cgi/viewcontent.cgi?article $=1068 \&$ context $=$ jmle

Center for Applied Special Technology (CAST). (2011). Response to the US Department of Education's Assessment Technology Standards Request for Information (RFI). Retrieved from http://www2.ed.gov/programs/racetothetop-assessment/rfi-response/castassessment-rfi-response.pdf

Christensen S. L., \& Thurlow, M.L. (2004). School dropouts: Prevention considerations, interventions, and challenges. Current Directions in Psychological Science, 13(1), 36-39. https://doi.org/10.111.j.09637214.2004.01301010.x

Coiro, J., Castek, J., \& Quinn, D. J. (2016). Personal inquiry and online research: Connecting learners in ways that matter. The Reading Teacher, 69(5), 483-492. https://doi.org/10.1002/trtr.1450

Common Core State Standards Initiative. (2013). About the Standards. Retrieved from http://www.corestandards.org/about-the-standards/developmentprocess/

Cope, B., \& Kalantzis, M. (2009). Ubiquitous learning: An agenda for educational transformation. In B. Cope \& M. Kalantzis, Ubiquitous learning (pp. 314). Urbana and Chicago, IL: University of Illinois Press.

Csikszentmihalyi, M. (1990). Flow: The psychology of optimal experience. New York, NY: Harper \& Row. 
Dewey, J. (1934). Art as experience (17th ed.). New York, New York: HG.P. Putnam's Sons.

Friesem, Y. (2016). Empathy for the digital age: Using video production to enhance social, emotional, and cognitive skills. In S. Tettegah, \& D. Espelage (Eds.), Emotions, technology, and behaviors (pp. 21-45). San Diego, CA: Academic Press. https://doi.org/10.1016/B978-0-12-801873$\underline{6.00002-9}$

G-Star School for Film Animation and Performing Arts. (2015). Public Service Announcement - Air, Public Service Announcement - Pythons Class Project, Palm Springs, FL

Gardner, H., \& Davis, K. (2013). The app generation: How today's youth navigate identity, intimacy, and imagination in a digital world. New York, NY: Yale University Press.

Glass, D., Meyer, A., \& Rose, D. H. (2013). Universal design for learning and the arts. Harvard Educational Review, 83(1), 98-119.

Guthrie, J. T., Wigfield, A., \& You, W. (2012). Instructional contexts for engagement and achievement for reading. In S. L. Christenson, A. L. Reschly, \& C. Wylie (Eds.), Handbook of research on student engagement (pp. 601-634). New York, NY: Springer Science+Business Media, LLC.

Harste, J. C. (2014). Transmediation: What art affords our understanding of literacy. Literacy Research Association Yearbook, 63, 88-103. Retrieved from http://www.tucsontawl.org/Tucson_TAWL/Spring_Conference_files/Tran smediation\%20LRA\%202014.pdf

Henry, L. A., Castek, J., O’Byrne, W. I., \& Zawilinski, L. (2012, June). Using peer collaboration to support online reading, writing, and communication: An empowerment model for struggling readers. Reading \& Writing Quarterly: Overcoming Learning Difficulties, 28(3), 279-306. https://doi.org/10.1080/10573569.2012.676431

Hobbs, R. (2010). Digital and Media Literacy: A Plan of Action (White Paper). Washington, DC: The Aspen Institute. Retrieved from http://www.atalm.org/sites/default/files/Digital_and_Media_Literacy_A_P lan_of_Action.pdf

Hobbs, R. (2016, June). Experience, Immersion and critical distance: VR/AR in Education. Ed Tech Mindset, 24-26. Retrieved from http://mediaeducationlab.com/sites/default/files/VREducation_0.pdf

Hubbard, G. T. (2012). Discovering constructivism: How a project-oriented activity-based media production course effectively employed constructivist teaching principles. Journal of Media Literacy Education, 4(2), 159-166.

Jeong, H., \& Hmelo-Silver, C. (2016). Seven affordances of computer-supported collaborative learning: How to support collaborative learning? How can technologies help? Educational Psychologist, 51(2), 1-19. https://doi.org/10.1080/00461520.2016.1158654 
Kiili, C., Coiro, J., \& Hämäläinen, J. (2016). An online inquiry tool to support the exploration of controversial issues on the Internet. Journal of Literacy and Technology, 17 (1-2), 31-52.

Koh, E., Shibani, A., Pei-Ling Tan, J., \& Hong, H. (2016). A pedagogical framework for learning analytics in collaborative inquiry tasks: an example from a teamwork competency awareness program. ACM Digital Library, 74-83. https://doi.org/10.1145/2883851.2883914

Lanter, E. (2005). Language-based learning disabilities: Intrinsic and extrinsic causes. Language-Based learning disabilities, 15(43), 24. http://speechlanguage-pathology-audiology.advanceweb.com/Article/Language-BasedLearning-Disabilities.aspx

Leach, A. M. (2014). Literacy learning and assessment for the digital age. In M. Khosrow-Pour (Ed.), Encyclopedia of information science and technology (3rd ed. pp. 2555-2576). Hershey, PA: IGI Global. https://doi.org/10.4018/978-1-4666-5888-2.ch249

Leach, A. M. (2015). Struggling adolescent readers immersed in a multimodal literacy project: A motivation, comprehension, and academic engagement case study (Doctoral dissertation). Available from ProQuest. (TX8-102787)

Leu Jr., D. J., Kinzer, C. K., Coiro, J. L., \& Cammack, D. W. (2004). Toward a theory of new literacies emerging from the Internet and other information and communication technologies. In R. B. Ruddell, N. J. Unrau. Theoretical Models and Processes of Reading, 5th edition. (pp. 15701613). Newark DE: International Reading Association.

Lewis-Charp, H., \& Law, T. (2014). Student-centered learning: City Arts and Technology High School. Retrieved from https://edpolicy.stanford.edu/sites/default/files/publications/studentcentered-learning-city-arts-and-technology-high-school_0.pdf

Markova, D., \& McArthur, A. (2015). Collaborative intelligence: Thinking with people who think differently. New York, NY: Spiegal \& Grau.

McElhone, D. (2012). Tell us more: Reading comprehension, engagement, and conceptual press discourse. Reading Psychology, 33, 525-561. https://doi.org/10.1080/02702711.2011.561655

McMaster, K. L., Espin, C. A., \& Van den Broek, P. (2014). Making connections: Linking cognitive psychology and intervention research to improve comprehension of struggling readers. Learning Disabilities Research \& Practice, 29(1), 17-24. https://doi.org/10.1111/ldrp.2014.29.issue$1 /$ issuetoc

Miller, S. (2013). A research metasynthesis on digital video composing in classrooms: An evidence-based framework toward a pedagogy for embodied learning. Journal of Literacy Research, 45(4), 386-430. https://doi.org/10.177/1086296X13504867

National Association for Media Literacy Education. (NAMLE). (2007). Core principles of media literacy education in the United States. Retrieved from https://namle.net/publications/core-principles/ 
National Association for Media Literacy Education. (NAMLE). (2014). Media literacy education \& the common core state standards. Retrieved from https://namleboard.files.wordpress.com/2015/04/namlemleccssguide.pdf

National Center for Research in Policy and Practice. (2016). http://ncrpp.org/

Pianta, R. C., Hamre, B. K., \& Allen, J. P. (2012). Teacher-student relationships and engagement: Conceptualizing, measuring, and improving the capacity of classroom interactions. In S. L. Christenson, A. L. Reschly, \& C. Wylie (Eds.), Handbook of research on student engagement (pp. 365-386). New York: Springer.

Pouw, W. T., Van Gog, T., \& Paas, F. (2014). An embedded and embodied cognition review of instructional manipulatives. Educational Psychology Review, 26(1), 51-72. https://doi.org/10.1007/s10648-014-9255-5

Rumberger, R. W., \& Rotermund, S. (2012). The relationship between engagement and high school dropout. In S. L. Christenson, A. L. Reschly, \& C. Wylie (Eds.), Handbook of research on student engagement (pp. 491-513). New York, NY: Springer.

Schneider, B., \& Blikstein, P. (2015). Unraveling students' interaction around a tangible interface using Multimodal Learning Analytics. Journal of Educational Data Mining, 7(3), 89-116. Retrieved from http://www.educationaldatamining.org/JEDM/index.php/JEDM/article/vie w/JEDM102

Smith, B. E. (2014). Beyond words: A review of research on adolescents and multimodal composition. In R. Ferdig, \& K. Pytash (Eds.), Exploring multimodal composition and digital writing (pp. 1-19). Hershey, PA: IGI Global. https://doi.org/10.4018/978-1-46664345-1.ch001

Souma, A., \& Casey, D. (2015). The benefits of Universal Design for students with psychological disabilities. In S. E. Burgstahler (Ed.), Universal design in higher education: From principles to practice (2nd ed., pp. 131138). Cambridge, MA: Harvard Education Press.

Spires, H. A., Hervey, L. G., Morris, G., \& Stelpflug, C. (2012). Energizing project-based inquiry: Middle-grade students read, write, and create videos. Journal of Adolescent \& Adult Literacy, 55(6), 483-493. https://doi.org/10.1002JAAL.00058

Stankov, L., Morony, S., \& Lee, Y. P. (2014). Confidence: the best non-cognitive predictor of academic achievement? Educational Psychology: An International Journal of Experimental Educational Psychology, 34(1), 928. https://doi.org/10.1080/01443410.2013.814194

Stolz, S. A. (2014). Embodied learning. Educational Philosophy and Theory, 47(5), 474-487. https://doi.org/10.1080/00131857.2013.879694

Swaggerty, E., Birdyshaw, D., McGriff, M., Rutherford, A., Lewis-Spector, J., Leach, A. M., \& Fine, J. (2016, December). Beyond state requirements: Examining teacher preparation for literacy instruction in U.S. teacher education programs. Paper presented at the Literacy Research Association, Nashville, TN.

Transformative Learning Technologies Lab. (2016). https://tltl.stanford.edu 
Tucker, M. (2016, February 25). Why the common core will be declared a failure [Blog post]. Education Week. Retrieved from http://blogs.edweek.org/edweek/top performers/2016/02/charles fadel on _what students need to know_and be able to do.html

U.S. Department of Education Office of Educational Technology. (2016). Future ready learning: Reimagining the role of technology in education (ED-04CO-004/0010). Washington, DC: Government Printing Office.

Worsley, M. (2012). Multimodal Learning Analytics: enabling the future of learning through multimodal data analysis and interfaces. In ICMI'12 Proceedings of the ACM International Conference on Multimodal Interaction (pp. 353-356). https://doi.org/10.1145/2388676.2388755

Worsley, M. \& Blikstein, P. (2013). Towards the development of multimodal action based assessment. In Proceedings of the Third International Conference on Learning Analytics and Knowledge (LAK '13), Leuven, Belgium. (pp. 94-101). https://doi.org/10.1145/2460296.2460315

Yang, Y. (2016). Making space for active learning: The art and practice of teaching. Harvard Educational Review, 86(1), 143-152. https://doi.org/10.17763/0017-8055.86.1.143 